Revista de
Economild
Contemporâned

Articles

https://revistas.ufrj.br/index.php/rec | www.scielo.br/rec

\title{
ESTIMATING THE DEMAND FOR BROADBAND SERVICES IN BRAZIL: ANALYSIS BY A DISCRETE-CHOICE MODEL
}

\begin{abstract}
Tainá Leandro ${ }^{a}$
Victor Gomes ${ }^{b}$

${ }^{2}$ Specialist in Public Policy and Governmental Management for the Ministry of Economic Affairs, Brazilian Federal Government. Brasilia, DF, Brazil. ORCID: https://orcid.org/0000-0003-4502-3292.

${ }^{b}$ Professor at the Department of Economics, University of Brasilia. Brasilia, DF, Brazil. ORCID: https://orcid.org/0000-0002-6838-7294.
\end{abstract}

Manuscript received on 2018/05/10 and accepted for publication on 2019/03/07.

\begin{abstract}
Discrete-choice models were used to estimate the demand for broadband services in Brazil. Results indicate an elastic demand for fixed broadband. The demand price elasticity is greater for municipalities that rely on more than one economic group offering broadband: the monopoly will set the price for the broadband services to minimize competition between plans in the same category. Therefore, consumer's capability to react to higher prices is reduced. In addition, the possibility of purchasing broadband services in tripleplay bundles has a positive effect on market share in those municipalities with two or more groups providing broadband services.
\end{abstract}

KEYWORDS: antitrust; telecommunications; broadband; asymmetric competition; elasticity of demand.

JEL CODES: L11.

Corresponding Author: Tainá Leandro

E-mail address: tainaleandro74@gmail.com 


\section{ESTIMANDO A DEMANDA POR BANDA LARGA NO BRASIL: UMA ANÁLISE POR MEIO DE MODELOS DE ESCOLHA DISCRETA}

RESUMO: A análise empírica estima a demanda por banda larga fixa residencial no Brasil por meio do modelo de escolha discreta Nested Logit. Os resultados indicam que a demanda é elástica. A elasticidade preço da demanda é maior para os municípios que contam com mais de um grupo econômico ofertando banda larga. Esse resultado é intuitivo na medida que um monopólio precificará os serviços de banda larga por ele ofertados de forma a minimizar a competição entre planos pertencentes a uma mesma faixa. Assim, a habilidade de o consumidor responder a preços mais altos é minorada. Além disso, a oferta dos serviços de banda larga em pacotes triple play tem efeito positivo na participação de mercado naqueles municípios que contam com a presença de mais de um grupo econômico nesse segmento.

PALAVRAS-CHAVE: concorrência; telecomunicações; banda larga; competição assimétrica; elasticidade da demanda. 


\section{INTRODUCTION}

Brazil has put in a great deal of government effort in incentive plans ${ }^{1}$ and regulatory actions $^{2}$ to foster the development of the broadband market. Nonetheless, because of lacking data, little is known about the demand for this service in small-sized Brazilian municipalities, especially regarding consumers' price sensitivity and preferences.

The present study seeks to fill this gap by using a unique database on the supply of broadband by the major telecommunications companies, including information about nearly 1,800 municipalities, providing a comprehensive outlook on the demand for this service in Brazil. Discrete-choice models were used to estimate the demand for Internet services in the Brazilian market, with a primary focus on fixed broadband services, taking into account product characteristics such as speed, Wi-Fi, bundled services, as well as characteristics of the companies such as size, brand strength, and reputation as main determining factors for the demand of these services.

Following the guidelines proposed by Berry (1994) and Verboven (1996), we estimate the aggregate demand using discrete-choice models of product differentiation with unobservable characteristics, based upon the one-level and two-level nested logit models.

The one-level nested logit model uses information on the demand for broadband from 1,830 municipalities, in which the companies that offer broadband services jointly hold at least $90 \%$ of the market share. In this model, the products are nested according to ranges of speed, with larger substitutability between the services in those ranges that are similar to each other. Results indicate an elastic demand (price elasticity of -4.5 to -5.3) for broadband services in Brazil positively related to the percentage of urban population, GDP per capita, and schooling. When other factors are controlled for, speed has a positive effect on the market share. The offer of triple play bundles ${ }^{3}$ did not show a significant effect on the specification that best fits the data.

It should be noted that service plans in lower ranges of speed are more inelastic than those in other ranges. In fact, there appears to be an effect of satiety for speeds, on average, greater than $50 \mathrm{Mbps}$, as results indicate that consumers are less prone to pay for speeds within this range (price elasticity of -11.5 to -13.7 ). The price elasticity of demand is larger for municipalities with more than one economic group in charge of

\footnotetext{
1 For instance, the National Broadband Plan (PNBL).

2 Such as price transparency and conditions for the supply of products and services to the final consumer, nondiscrimination rules, and infrastructure sharing policies (HENRIKSEN, 2012).

3 Broadband services offered, in bundles, with pay TV and landline telephone.
} 
broadband service delivery. The monopoly will set the price for the broadband services to minimize competition between plans in the same category. Therefore, consumer's capability to react to higher prices is reduced.

The second model seeks to verify whether same-size companies are perceived by consumers as near substitutes for each other and, consequently, whether competition within the municipality is directly affected by the presence of more than one large group in the broadband market, as pointed out by ANATEL (2016). Thus, a two-level nested logit model was used to estimate the substitutability pattern of broadband services, sorting them by range of speed and classifying providers into three categories, as a proxy for company size: national, regional, and local. In this model, consumers first decide on the range of speed and then if they are going to choose a local, regional, or national group.

Since this categorization applies only to consumers who have the opportunity to choose among different companies, the model was implemented by using a subsample of the previous one, which includes 194 municipalities with at least two groups offering broadband services. The price elasticity of demand per range of speed and the number of economic groups within the municipality are consistent with those obtained in the previous model. When assessed separately, according to economic group size, the price elasticities of demand are higher for national companies, which have a larger number of subscribers when compared with regional or local ones. However, the cross elasticities at the first level show an inverse pattern, and this indicates asymmetric competition in the market: the demand for products from smaller companies is more severely affected by the presence of national companies than the other way around.

The present study also seeks to assess the effect of triple play bundles on the demand for fixed broadband in those municipalities where there is more than one economic group. This commercial strategy has been increasingly adopted by service providers - in 2016, 63\% of the municipalities had an economic group which already implemented it - and it has arguable effects on the competition dynamics of telecommunications markets. Results reveal that the supply of broadband services in triple play bundles has a positive effect on market share. This effect may be associated with the preference of consumers for bundled services or may result from the discounts given in the purchase of triple play bundles - about $22 \%$. In addition, providers may offer highly demanded speeds in triple play bundles as a way to stimulate consumers to purchase other products.

After this introduction, Section 2 provides a brief review of the literature on the estimation of demand for broadband services. Section 3 presents the database used in the empirical analysis. Section 4 describes the nested logit model for aggregate data. Section 5 discusses the results obtained for the one-level and two-level nested logit models, in addition to the price elasticities of demand and cross elasticities for broadband services in Brazil. 


\section{PREVIOUS LITERATURE}

Estimation of demand for broadband services by discrete-choice models is commonplace in the international literature, and these models are used mainly to assess competition between different infrastructure networks. Kridel et al. (2001) used household data to estimate the demand for home broadband in the USA by means of a nested logit model. They concluded that the demand for DSL is elastic and that, accordingly, services based on $\mathrm{x}$ DSL and cable modem technologies belong to the same relevant market.

Ida and Kuroda (2006) also employed the nested logit model using household data to assess the broadband market in Japan. When they estimated the price elasticities of demand, they concluded that the demand for DSL was inelastic, whereas the demand for FTTH and cable were elastic. Moreover, the demand for services with higher DSL speeds was elastic, owing to the fiercer competition with FTTH and cable networks, as with very low speeds, which would compete with dial-up Internet access and ISND.

Cardona et al. (2007) assessed competition between DSL, cable, and mobile broadband in the Austrian market and used the estimated price elasticities in the nested logit model to perform the hypothetical monopolist test. They used household data from a survey conducted by the Austrian Regulatory Authority for Broadcasting and Telecommunications (RTR), revealing individual choice in the purchase of broadband services. They concluded that the demand was elastic (greater than 2.5) in markets in which there were several types of broadband services (DSL, cable, and mobile), indicating that these different broadband technologies were near substitutes for each other.

The Brazilian empirical literature on the broadband market focuses mainly on how competition, demographic, and economic variables affect the penetration of broadband Internet access in Brazilian municipalities (MACEDO and CARVALHO, 2010; HENRIKSEN and MUELLER, 2012; BAIGORRI, 2014). The study undertaken by Freitas and Gomes (2013) is noteworthy in that they sought to identify the main factors influencing the demand for Internet access at the household level in Brazil. They did so by estimating price elasticity through two discrete-choice models: multinomial logit model and the method of Berry, Levinsohn, and Pakes (BLP). Using household data (CTIC household survey) for the years 2010 and 2011, they assessed substitutability between different types of broadband networks: (i) cable; (ii) FWA (Fixed Wireless Access 20); or (iii) mobile. Their results suggest that fixed and mobile services are substitutes for each other at different levels, but, in general, consumers seem to prefer mobile broadband services.

As in the study by Freitas and Gomes (2013), the present paper seeks to assess the demand for Internet in Brazil, focusing on home broadband, using discrete-choice 
models, more specifically, nested logit models. However, it differs from the previous literature, as the scope is not to estimate how demand varies as a function of the technology used for service delivery. The major determining factors included product characteristics, such as speed and tripleplay bundles, as well as corporate characteristics, such as size, brand strength and reputation.

\section{DATABASE}

Cross-sectional data containing information on prices and product characteristics (including whether bundled services are offered with pay TV and landline) were collected in the first half of 2016 directly from the webpages of the major Brazilian telecommunications companies. ${ }^{4}$

The data are local and make up an accurate database on the broadband offers available to potential subscribers in a given municipality. Therefore, it was not necessary to impute this information, as it is usually the case in discrete-choice analyses for the broadband market (IDA and KURODA, 2006; CARDONA et al., 2007; FREITAS and GOMES, 2013).

The total database has about 4,000 municipalities. Nonetheless, in several of them it was not possible to gather information from all firms with broadband consumers. ${ }^{5}$ In order for the database to be an accurate set of the options available to a given subscriber, only municipalities whose market share was greater than $90 \%$ were selected. A total of 1,829 municipalities were included in the analysis of which 1,634 are covered by a single company, in most cases $(1,311)$ by Oi. In 194 municipalities, at least two companies offer broadband services. Figure 1 shows the geographic distribution of the municipalities whose information is included in the database according to the number of economic groups that deliver this kind of service.

4 Performed between February 20 and March 10, 2016.

5 Considering the difficulty of finding information regarding broadband offers from smaller companies, the databases are more focused on national and regional firms. Because of that, in municipalities where there is a strong local firm, data was incomplete. 


\section{Figure 1 - Municipalities whose information is included in the database}

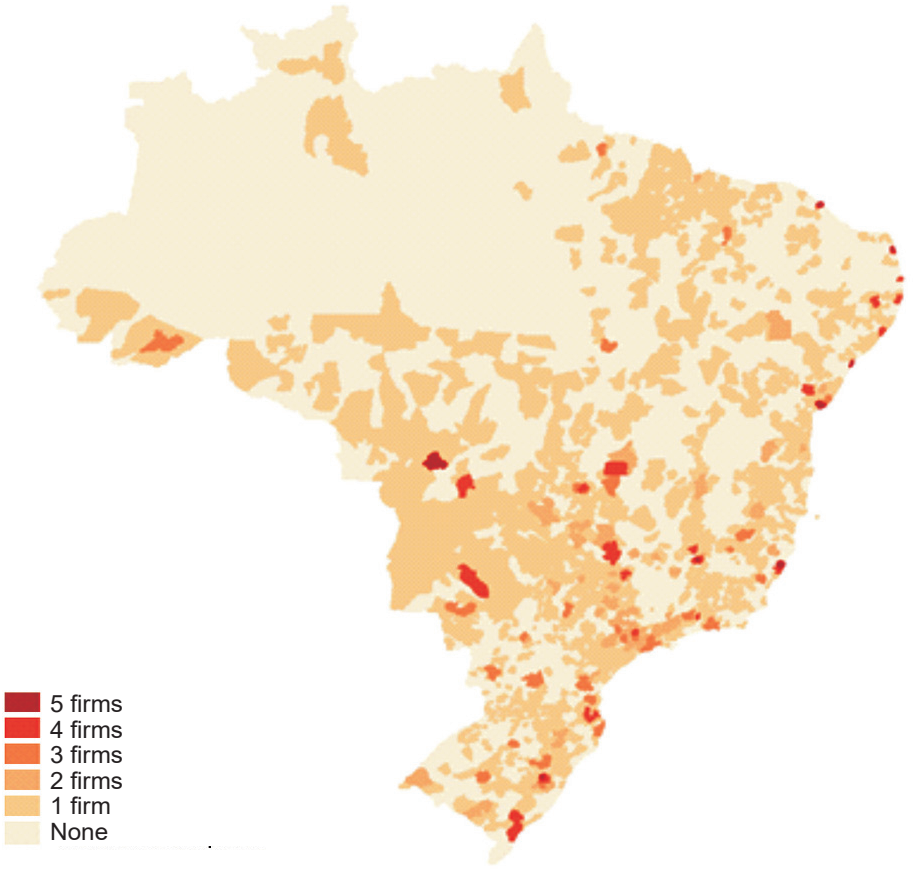

Source: Authors' elaboration based on data compiled for the analysis

The data on the number of subscribers to each of the plans available on the webpages of the telecommunications companies were imputed according to the information contained in the broadband database of ANATEL, the Brazilian Telecommunications Agency. ${ }^{6}$ The ANATEL provides information on the number of accesses per municipality and per speed ( $0 \mathrm{kbps}$ to $512 \mathrm{kbps}, 512 \mathrm{kbps}$ to $2 \mathrm{Mbps}, 2$ Mbps to $12 \mathrm{Mbps}, 12 \mathrm{Mbps}$ to $34 \mathrm{Mbps}$, and > $34 \mathrm{Mbps}$ ) for each telecommunications company. Most companies offer just one service plan per range of speed, allowing for accurate data imputation. As pointed out by Corrado and Ukhaneva (2016), if a company offered more than one product per range of speed, the number of subscribers in that range was divided by the number of products. ${ }^{7}$

6 Available at: <http://ftp.anatel.gov.br/dados/Acessos/Comunicacao_Multimidia/>.

7 The number of national subscribers to each range of speed was available for Algar, Telecom Américas, and Telefônica. In this case, the ratio between the speeds in the same range was imputed according to the one observed in the national database. 
Table 1, which displays the descriptive statistics, shows that the database includes around 9,500 offers for broadband services by 10 economic groups of different sizes. The average price of broadband services is $\mathrm{R} \$ 116.55$ and the average speed is 22.11 Mbps. In the selected municipalities, the average of households without broadband access (So) was high: $81.15 \%$.

Table 1 - Descriptive statistics of the variables used in the econometric models

\begin{tabular}{lccccc}
\hline Variable & Obs. & Mean & Standard deviation & Minimum & Maximum \\
\hline Speed & 9,501 & 22.111 & 33.786 & 0.25 & 300 \\
Price & 9,501 & 116.553 & 50.970 & 19.9 & 799.9 \\
Wi-Fi dummy & 7,505 & 0.751 & 0.433 & 0 & 1 \\
Bundle dummy & 9,501 & 0.749 & 0.433 & 0 & 1 \\
Potential market (So) & 9,501 & 0.811 & 0.161 & 0.298 & 0.996 \\
MHDI Schooling & 9,501 & 0.609 & 0.098 & 0.299 & 0.825 \\
Log of GDP per capita & 9,501 & 9.749 & 0.738 & 8.084 & 12.446 \\
\% Urban population & 9,501 & 77,028 & 21,224 & 9,350 & 100,000 \\
\% Young population & 9,501 & 41,275 & 3,143 & 29,340 & 69,180 \\
Total population & 9,501 & $187,710.4$ & $756,479.8$ & 836 & $1.20 \mathrm{e}+07$ \\
\hline
\end{tabular}

Source: Authors' elaboration based on data provided by ANATEL and IBGE and compiled for the analysis.

As it will be discussed in detail in the upcoming sections, for estimation of the demand for fixed broadband, services were grouped into four ranges of speed: (i) 0 to $5 \mathrm{Mbps}$; (ii) 6 to $20 \mathrm{Mbps}$; (iii) 21 to $49 \mathrm{Mbps}$; and (iv) > $50 \mathrm{Mbps}$. The first three ranges jointly account for $90 \%$ of the offers. Of the total amount of broadband services, $74.9 \%$ are offered with a discount for customers who purchase landline and pay TV services from the same company, but this is more frequent for speeds lower than 50 Mbps, as shown in Table 2.

Table 2 - Offer of broadband services per range of speed, speed, and average price

\begin{tabular}{|c|c|c|c|c|c|c|}
\hline \multirow[t]{2}{*}{ Range of speed } & \multirow[t]{2}{*}{ Speed } & \multirow[t]{2}{*}{ Average price } & \multicolumn{2}{|c|}{ Offers } & \multicolumn{2}{|c|}{ Triple Play } \\
\hline & & & $\#$ & $\%$ & $\#$ & $\%$ \\
\hline \multirow[t]{6}{*}{0 to $5 \mathrm{Mbps}$} & 0.25 & 31.73 & 336 & $3.54 \%$ & 0 & $0 \%$ \\
\hline & 0.5 & 42.4 & 25 & $0.26 \%$ & 25 & $100 \%$ \\
\hline & 1 & 62.73 & 23 & $0.24 \%$ & 21 & $91.30 \%$ \\
\hline & 2 & 96.42 & 2,053 & $21.61 \%$ & 1,701 & $82.85 \%$ \\
\hline & 3 & 104.35 & 4 & $0.04 \%$ & 2 & $50.00 \%$ \\
\hline & 4 & 55.85 & 472 & $4.97 \%$ & 134 & $28.39 \%$ \\
\hline
\end{tabular}


Table 2 - Offer of broadband services per range of speed, speed, and average price (continuation)

\begin{tabular}{|c|c|c|c|c|c|c|}
\hline \multirow[t]{2}{*}{ Range of speed } & \multirow[t]{2}{*}{ Speed } & \multirow[t]{2}{*}{ Average price } & \multicolumn{2}{|c|}{ Offers } & \multicolumn{2}{|c|}{ Triple Play } \\
\hline & & & $\#$ & $\%$ & $\#$ & $\%$ \\
\hline & 5 & 68.84 & 21 & $0.22 \%$ & 8 & $38.10 \%$ \\
\hline \multirow[t]{5}{*}{6 to $20 \mathrm{Mbps}$} & 6 & 59.9 & 2 & $0.02 \%$ & 2 & $100 \%$ \\
\hline & 7 & 41.56 & 9 & $0.09 \%$ & 1 & $11.11 \%$ \\
\hline & 8 & 60.87 & 29 & $0.31 \%$ & 0 & $0 \%$ \\
\hline & 10 & 107.23 & 1,549 & $16.30 \%$ & 1,202 & $77.60 \%$ \\
\hline & 15 & 131.1 & 1,590 & $16.74 \%$ & 1,549 & $97.42 \%$ \\
\hline \multirow[t]{5}{*}{21 to $49 \mathrm{Mbps}$} & 20 & 148.57 & 24 & $0.25 \%$ & 14 & $58.33 \%$ \\
\hline & 25 & 132.37 & 1,654 & $17.41 \%$ & 1,411 & $85.31 \%$ \\
\hline & 30 & 113.98 & 167 & $1.76 \%$ & 130 & $77.84 \%$ \\
\hline & 35 & 151.57 & 643 & $6.77 \%$ & 611 & $95.02 \%$ \\
\hline & 40 & 107.01 & 3 & $0.03 \%$ & 3 & $100 \%$ \\
\hline \multirow[t]{8}{*}{$>50 \mathrm{Mbps}$} & 50 & 113.99 & 232 & $2.44 \%$ & 36 & $15.52 \%$ \\
\hline & 60 & 154.37 & 133 & $1.40 \%$ & 133 & $100 \%$ \\
\hline & 64 & 105.62 & 28 & $0.29 \%$ & 0 & $0 \%$ \\
\hline & 100 & 115.8 & 142 & $1.49 \%$ & 10 & $7.04 \%$ \\
\hline & 120 & 328.18 & 128 & $1.35 \%$ & 128 & $100 \%$ \\
\hline & 150 & 234.9 & 90 & $0.95 \%$ & 0 & $0 \%$ \\
\hline & 200 & 134.38 & 129 & $1.36 \%$ & 0 & $0 \%$ \\
\hline & 300 & 334.9 & 15 & $0.16 \%$ & 0 & $0 \%$ \\
\hline Total & & & 9,501 & $100.00 \%$ & 7,121 & $74.95 \%$ \\
\hline
\end{tabular}

Source: Authors' elaboration based on data compiled for the analysis.

\section{EMPIRICAL MODEL}

The present empirical analysis uses the nested logit model to estimate the demand in differentiated products markets. This model relaxes the assumption of independence of irrelevant alternatives (IIA) found in conventional multinomial logit models, providing more plausible substitution patterns. This allows estimations to capture the response of consumers to unobservable characteristics of similar products by grouping them into the same category (nest).

However, the nested logit cross-price elasticities within the same group are symmetric, as well as the substitution outside a group to all other groups. Because of that, some studies adopt the full random coefficients logit model of Berry, Levinsohn and Pakes (BLP) (1995). These studies include random coefficients for continuously measured product characteristics, and, so, products with similar continuous characteristics 
will be near substitutes. So, BLP is a generalization of logit demand models, allowing for unobserved product characteristics. BLP is the ideal model to be applied to aggregate market data but we do not have enough data to use this procedure. We should have more product characteristics and distributional data on household income and other characteristics. On the other hand, the nested logit is a good way to break down the IIA problem allowing only correlations between products that belongs to a same category, i.e., that belongs to the same nest. In the Brazilian broadband market, a particularly important aspect of consumer heterogeneity is the firm size (if is national, regional or local), which the nested logit model captures reasonably well.

Originally, discrete-choice models estimate the market demand from individual consumers' choices. Following the approach proposed by Berry (1994), the model was extended for estimation of aggregate choices, which is more appropriate for the available data. Demand results from the sum of individual choices of different consumers, whose utility depends on product characteristics and individual preferences. Therefore, the market share of each product derives from the aggregation of individual demands.

The model also considers the possibility of consumers deciding not to purchase any of the products by including an outside good in the analysis, causing a price increase to reduce the overall sales. In the present study, the potential market for fixed broadband services is the number of households in the municipality and, consequently, the outside good was defined as the number of households of a given municipality subtracted from the total number of broadband accesses in that municipality.

There are $R$ independent markets in which $N_{r}$ firms offer a broadband service $j$. For each product $j$ in market $R$, its characteristics are represented by vector $x_{j r}$ (for the sake of simplicity, subscript $r$ will be disregarded). The model also raises the possibility that characteristics unobservable to the econometrician $\left(\xi_{j}\right)$, such as the perception of quality by the consumer or the existence of aftermarket services, will affect the demand for the product.

Each individual $i$ chooses product $j$ that maximizes the utility $u_{i j}$, which depends on the product's characteristics and on consumer's preference:

$$
u_{i j}=\delta_{j}+v_{i j}
$$

In (1), $\delta_{j}$ is the average level of utility inherent to product $j$ and $v_{i j}$ stands for a heteroskedastic error with zero mean, which captures the random effects of the preference parameters of consumer $i$.

In this context, $\delta_{j}$ can be represented by the equation below: 


$$
\delta_{j}=x_{j} \beta-a p_{j}+\xi_{j}
$$

In (2), $\beta_{k}$ is the average level of preference of consumers for $j$; $\alpha$ is the scalar coefficient of price; $p j$ is the price of product $j$, and the term $\xi_{j}$ might be thought of as the consumers' average preference regarding unobservable characteristics.

Additionally, $v_{i j}$ is the demand parameter that captures specific attributes or conditions of consumer $i$ not observed by the econometrician. The present empirical analysis uses the nested logit model, in which products are categorized into $G+1$ exhaustive and mutually exclusive groups, $G=0,1, \ldots, G$, and the outside good is the only element of group 0 .

Thus, for product $j \in \aleph_{g}, v_{i j}$ is represented by the equation below:

$$
v_{i j}=\zeta_{i g}+(1-\sigma) \epsilon_{i_{j}}
$$

The variable $\zeta$ denotes characteristics that are common to all products in group $g$ and its distribution function depends on the level of correlation between the alternatives from the same subgroup $\sigma$, where $0 \leq \sigma<1 . \epsilon_{i j}$ is the distribution of these preferences relative to the mean, considering an independent and identically distributed (i.i.d) random term, following the type I extreme value distribution. Given that $\epsilon_{i j}$ follows this distribution, $v_{i j}$ also has a type I extreme value distribution.

Supposing that $d_{i j}$ is a dummy variable equal to 1 if $j \in \aleph_{g}$, it is possible to rewrite (1) as:

$$
u_{i j}=\delta_{j}+\sum_{g}\left[d_{j i} \zeta_{i g}\right]+(1-\sigma) \epsilon_{i j} u_{i j}
$$

To identify the share of a given product $j$ from group $g$, it is necessary to know: (i) the market share of $j$ conditional to belonging to group g and (ii) the market share of group $g$, in which $j$ is included. Thus, considering vi i.i.d. e.v.t.1 (type I extreme value) - the market share is given by:

$$
s_{j}(\delta, \sigma)=\bar{s}_{j / g}(\delta, \sigma) \bar{s}_{g}(\delta, \sigma)=\left[e^{\delta_{j} /(1-\sigma)}\right] / D_{g}^{\sigma}\left[\sum_{g} D_{g}^{(1-\sigma)}\right]
$$

According to Berry (1994), as the average level of utility of the outside good was normalized to zero and this is the only product that belongs to group zero, i.e., $\left(\delta_{0} \equiv 0, D_{0}=1\right)$, then:

$$
s_{0}(\delta, \sigma)=1 /\left[\sum_{g} D_{g}^{(1-\sigma)}\right]
$$


By applying the ratio between $s_{j}$ and $s_{0}$, we have:

$$
\frac{s_{j}(\delta, \sigma)}{s_{0}(\delta, \sigma)}=\frac{\left[e^{\delta_{j} /(1-\sigma)}\right] / D_{g}^{\sigma}\left[\sum_{g} D_{g}^{(1-\sigma)}\right]}{1 /\left[\sum_{g} D_{g}^{(1-\sigma)}\right]}
$$

Taking the logs of market shares given by equation (8):

$$
\ln \left(s_{j}\right)-\ln \left(s_{0}\right)=\delta_{j} /(1-\sigma)-\sigma \ln \left(D_{g}\right)
$$

Taking into account equations (2) and (5), it is possible to rewrite (8) as:

$$
\ln \left(s_{j}\right)-\ln \left(s_{0}\right)=x_{j} \beta-\alpha p_{j}+\sigma \ln \left(\bar{s}_{j / g}\right)+\xi_{j}
$$

In (9), $s_{j}=\frac{q_{j}}{I}$, i.e., the market share of the product in relation to the potential market (number of households), and $s_{j / g}=\frac{q_{j}}{\sum_{j \in G} q_{j}}$, i.e., market share of product $j$
within its group $g$.

Therefore, demand parameter $\alpha, \beta$ and $\sigma$ of the one-level nested logit model can be obtained by a linear regression with instruments, as shown in (9). As demonstrated by McFadden (1978), it is necessary that $1 \geq \sigma \geq 0$ so that the estimated parameters are consistent with the random utility theory. When the coefficient is close to 1 , the error distribution tends to an i.i.d. of extreme value and the choice probabilities are given by the multinomial logit model. If the coefficient is close to zero, the error term becomes the utility. If parameters are greater than 1 , there is substitutability between the groups and product categorization is not consistent with the random utility theory.

Given that $\bar{s}_{j / g}$ is endogenous, it is necessary to have additional exogenous variables correlated with the products in each group. Usually, the characteristics of other products in the group, the number of products of a given company and of its competitors in each group or subgroup are used for this purpose (VERBOVEN, 1996; BJÖRNERSTEDT and VERBOVEN, 2013).

The present study also uses the two-level nested logit model. In this case, the set of products is split into $G$ groups, $g=0,1, \ldots, G$, and, just as in the one-level nested logit model, group 0 is degenerate, containing only the outside good. Moreover, each group $\mathrm{g}$ is divided into $H_{g}$ subgroups, $h=0,1, \ldots, H_{g}$. Each subgroup $h \in g$ contains $J_{h g}$ products, such that $\sum_{g=1}^{G} \sum_{h=1}^{H_{g}} J_{h g}=J$. Following Verboven (1996) and Björnerstedt and Verboven (2013), this model can be estimated by the linear equation below: 


$$
\ln \left(s_{j}\right)-\ln \left(s_{0}\right)=x_{j} \beta-\alpha p_{j}+\sigma_{1} \ln \left(\bar{s}_{j / h g}\right)+\sigma_{2} \ln \left(\bar{s}_{h / g}\right)+\xi_{j}
$$

In (10), $\bar{s}_{j / h g}=\frac{q_{j}}{\sum_{j \in H_{g}} q_{j}}$ is the market share of product $j$ within its subgroup $h$; $\bar{s}_{h / g}=\frac{\sum_{j \in H_{g}} q_{j}}{\sum_{h=1}^{H_{g}} \sum_{j \in H_{g}} q_{j}}$ is the market share of subgroup h relative to group $g ; \sigma_{1}$ is the correlation of consumer's preference for products that belong to the same subgroup $h$ of group $g ; \sigma_{2}$ is the correlation of consumer's preference for products from subgroups belonging to the same group $g$.

Finally, in order for the parameters estimated by the two-level nested logit model to be consistent with the random utility theory, $\sigma_{1}$ and $\sigma_{2}$ should have the following relationship: $1 \geq \sigma_{1} \geq \sigma_{2} \geq 0$ (BJÖRNERSTEDT and VERBOVEN, 2013b).

\section{EMPIRICAL ANALYSIS}

Two discrete-choice models were estimated. The first one uses a one-level nested logit model in which broadband services are sorted by ranges of speed based on supply data for 1,829 municipalities. The second one consists of a two-level nested logit model implemented for the 194 municipalities with two or more economic groups in the broadband sector. In this model, same-sized companies ${ }^{8}$ are perceived by consumers as near substitutes for each other.

Since $\bar{s}_{j / g}$ in the one-level model, and $\bar{s}_{h / g}$ and $\bar{s}_{j / h g}$ in the two-level model are endogenous, the correct identification of the parameters in the nested logit model requires the exogenous variables correlated with market shares within the group and subgroup to be included in the estimations (BERRY, 1994). In both models, a similar approach was used to deal with potential endogeneity problems. We adopted the identification assumption that the matrix of product characteristics is exogenous. Hence, in addition to the individual characteristics of the products, the number of products offered by competitors for each range of speed was used as instruments for the regression of the one-level nested logit model. This variable is an usual proxy for the cost structure of firms in multi-market analysis: for example, on average, a quality increase in the product characteristics should imply a cost rising. The two-level nested

\footnotetext{
8 National, regional, and local proxies for size.
} 
logit model employed the number of products offered in each group and subgroup, the number of products offered by competitors, and the average speed of the service offered within each subgroup and group as instruments.

Since we do not have access to the costs of each firm, an alternative is to use the socalled Hausman instruments. The Hausman instruments are the sum of prices in others local markets. Since similar products are offered across several regional markets, differences in prices should be accounted by differences in local costs. ${ }^{9}$

Following Nevo's strategy (2001), we used the state average price, excluding the price observed in the instrumented municipality, thereby controlling for the national components that affect the cost structure of a telecommunications firm - equipment, exchange rate and the investment opportunity cost. ${ }^{10}$ We used information collected from approximately 4,000 municipalities for the construction of this instrumental variable. Finally, to control for the network's externalities (strategy) present in the telecommunications sector, we used the number of firm' subscribers in the nearby towns.

\subsection{ONE-LEVEL NESTED LOGIT MODEL}

In the one-level nested logit model for aggregate data, broadband services with similar speeds are assumed to be near substitutes when compared to products at other speeds. A 512-kbts broadband plan will compete more fiercely with a 2-Mbps plan than an offer for $10 \mathrm{Mbps}$. Thus, offers were grouped into four ranges of speed: (i) 0 to $5 \mathrm{Mbps}$; (ii) 6 to $20 \mathrm{Mbps}$; (iii) 21 to $49 \mathrm{Mbps}$; and (iv) > $50 \mathrm{Mbps}$. Figure 2 shows the decision tree for the final consumer in the one-level nested logit model.

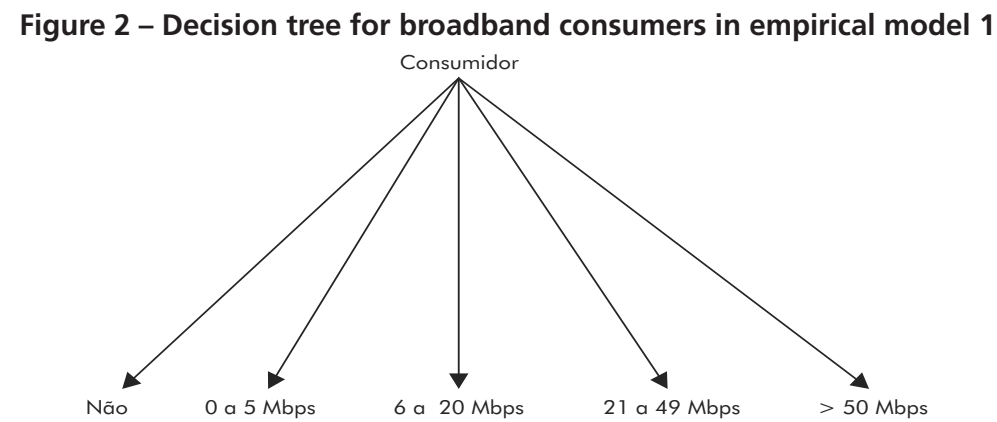

Source: Authors' elaboration based on data compiled for the analysis.

9 For a discussion on the use of instruments in demand estimation see Bresnaham (1997) and Berry and Haile (2016).

${ }_{10}$ Besides that, the unobservable cost that presumably goes into prices does not have a common factor across markets that is correlated to unobservable characteristics. For a discussion on the use of instruments in demand estimation see Bresnaham (1997) and Berry and Haile (2016). 
Although the total database has about 4,000 municipalities, the model was implemented using data from 1,829 due to lack of data for all localities. Considering the difficulty of finding information regarding broadband offers from smaller companies, the databases focus more on national and regional firms. However, they tend to operate in different geographical markets. Because of that, in several municipalities where the subscribers were divided between a national/regional firm and a local firm, the data was incomplete. In order that the database could be an accurate set of the options available to a given subscriber, it was selected only municipalities whose companies in the database has an aggregate market share greater than $90 \%$.

\subsubsection{RESULTS}

As discussed in Section 2, the nested logit model can be estimated by GMM with the following functional form:

$$
\ln \left(s_{j}\right)-\ln \left(s_{0}\right)=\alpha p_{j}+\beta_{1}+\beta_{2} \text { Speed }_{j}+\beta_{3} \text { Wifi }_{j}+\beta_{4} \text { Bundle }_{j m}+\sigma \ln \left(\bar{s}_{j / g}\right)+\theta Z+\xi_{j}
$$

Here, $s_{j}$ is the market share of product $j$ in municipality $m$; $s_{0}$ is the market share of the outside good, i.e., when a given household decides not to purchase broadband services; $\bar{s}_{j / g}=\frac{q_{j}}{\sum_{j \in \text { faixa } i} q_{j}}$ is the share of product $j$ as a fraction of the market share of the speed range to which it belongs; $p_{j}$ is the price of product $j$ in market $m$, endogenous variable in the model; Speed $_{j m}$ is the broadband speed offered in; $W i f i_{j m}$ is a dummy $=1$ if a Wi-Fi service is offered; Bundle ${ }_{j m}$ is a dummy $=1$ if the broadband service can be purchased in a triple play bundle; $Z$ are the characteristics of the municipalities that could affect the demand for broadband. The estimations included the following variables: log of GDP per capita, MHDI schooling, percentage of young population and percentage of urban population. $\xi_{j}$ are the services' unobservable characteristics to the econometrician.

Table 3 displays the results for two regressions. Both use as instruments the state's mean price, the number of offers made by its competitors, clustering on micro region dummies. Only the second one controls for offers from Telefônica, which is correlated with optical fiber communications networks, a more expensive technology. The estimations use robust standard errors for correction of heteroskedasticity. 
Table 3 - Results for estimations of the one-level nested logit model

\begin{tabular}{|c|c|c|}
\hline & (i) & (ii) \\
\hline \multirow[t]{2}{*}{$\ln \left(\bar{s}_{j / g}\right)$} & .74233038 & .72800485 \\
\hline & $(0.000)$ & $(0.000)$ \\
\hline \multirow[t]{2}{*}{ Price } & -.01879599 & -.01666353 \\
\hline & $(0.000)$ & $(0.000)$ \\
\hline \multirow[t]{2}{*}{ Speed } & .00904605 & .00592498 \\
\hline & $(0.002)$ & $(0.051)$ \\
\hline \multirow[t]{2}{*}{ Wi-Fi dummy } & -.52138864 & -.55958953 \\
\hline & $(0.000)$ & $(0.000)$ \\
\hline \multirow[t]{2}{*}{ Bundle dummy } & .78921698 & 1.2869006 \\
\hline & $(0.000)$ & $(0.000)$ \\
\hline \multirow[t]{2}{*}{ Per capta revenue } & .0019213 & .0018662 \\
\hline & $(0.000)$ & $(0.000)$ \\
\hline \multirow[t]{2}{*}{$\%$ young population } & .0094634 & .00436183 \\
\hline & $(0.353)$ & $(0.659)$ \\
\hline \multirow[t]{2}{*}{ MHDI - Schooling } & 4.4247239 & 4.3486739 \\
\hline & $(0.000)$ & $(0.000)$ \\
\hline \multirow[t]{2}{*}{$\%$ urban population } & .0189036 & .01855084 \\
\hline & $(0.000)$ & $(0.000)$ \\
\hline \multirow[t]{2}{*}{ Log of Scale } & .00118402 & .00111909 \\
\hline & $(0.000)$ & $(0.000)$ \\
\hline \multirow[t]{2}{*}{ Telefônica } & - & .90820531 \\
\hline & & $(0.000)$ \\
\hline \multirow[t]{2}{*}{ Constant } & -8.797 & -9.341 \\
\hline & $(0.000)$ & $(0.000)$ \\
\hline Instruments & \multicolumn{2}{|c|}{ \# of offers by competitors and Average regional prices } \\
\hline CenteredR $^{2}$ & 0.6908 & 0.7007 \\
\hline F Test & 26.42 & 28.28 \\
\hline Sargan (p-value) & 0.0109 & 0.0315 \\
\hline
\end{tabular}

Note: P-value in brackets.

Source: Data compiled by the authors.

The parameters of interest have the expected sign for all estimates: the price coefficient is negative and the coefficient associated with $\ln \left(\bar{s}_{j / g}\right)$ has sign and value consistent with the random utility theory, $1 \geq \sigma \geq 0$.

Regarding the characteristics of the services, the broadband speed parameter had a positive sign in the estimates, which indicates a positive effect on the market share of the services when controlled for by the other variables, whereas the Wi-Fi dummy had 
a negative sign. The demographic variables also had the expected signs. This is so because the percentage of urban population, the (log of) GDP per capita, and MHDI associated with schooling are positive, indicating that municipalities with higher income and higher levels of education have a larger penetration of broadband services.

Interestingly, the dummy associated with the triple play bundle is positive and statistically significant, indicating a beneficial effect on the demand for fixed broadband. On the one hand, this may be associated with the possibility of consumers preferring to purchase bundled services, as they will have a single invoice for all services (PRINCE, 2012; BEREC, 2010), or efficiencies arising from 'one-stop shopping', such as having to deal with a single customer service center (BUGHIN, 2007). On the other hand, this may also be a strategy adopted by service providers to offer highly demanded speeds as triple play services to stimulate consumers to buy other products from the company. This underscores the importance of assessing triple play bundles when investigating the demand for telecommunications services in Brazil.

Note that the estimates are reasonably appropriate for the available data with a centered $R^{2}$ of 0.69 and 0.70 , respectively. This indicates that the regressions can explain approximately $70 \%$ of the variations in market share of broadband services in the municipality. ${ }^{11-12}$

After this preliminary discussion, we now address the price elasticities of demand and the cross elasticities estimated by the model.

\subsubsection{ELASTICITIES}

The demand for broadband is elastic in both estimates (between 4,5 and 5,3), ${ }^{13}$ as shown in Table 4 . The cross elasticities for the products within the same range of speed vary from 3.5 to 4.2 and have significantly higher values than for the products in other ranges of speed (0.04 to 0.05$)$. This means that broadband offers are subjected to a greater competition when another product with similar speed is available.

\footnotetext{
${ }_{11}$ Note that the Sargan test is not fit to validate the instruments, but we also run the models by 2-step GMM imposing (where is the vector of instruments, and is the error term) and the results are very close to 2SLS estimation. Besides, we do not observe a not expected behavior is the instruments coefficients in the first stage and neither in the estimated elasticities. See Berry (1994) for a deeper discussion of the use of instruments in the nested logit model.

12 See the Appendix for OLS and instrumented variable models which indicates the instruments strength.

13 This section shows the modules of price elasticity of demand.
} 
Table 4 - Average elasticities for the one-level nested logit model

\begin{tabular}{lccc}
\hline & & (i) & (ii) \\
\hline Price elasticity & Mean & $-\mathbf{5 . 3 7 6}$ & $\mathbf{- 4 . 5 8 2}$ \\
Cross elasticity - group & S.D. & 4.241 & 3.529 \\
& Mean & $\mathbf{4 . 3 5 5}$ & $\mathbf{3 . 5 9 0}$ \\
Cross elasticity - nongroup & S.D. & 2.954 & 2.435 \\
& Mean & 0.051 & 0.045 \\
& S.D. & 0.077 & 0.068 \\
\hline
\end{tabular}

Source: Data compiled by the authors.

As shown in Table 5, the products in lower ranges of speed are more inelastic than those in the other ranges. This finding is in line with the elasticities estimated by Freitas and Gomes (2013), who also found a positive relationship between price elasticity of demand and broadband speed.

Table 5 - Average elasticities per range of speed (in Mbps) for the one-level nested logit model

\begin{tabular}{|c|c|c|c|c|}
\hline & \multicolumn{4}{|c|}{ (i) } \\
\hline Range of speed & 0 to 5 & 6 to 20 & 21 to 49 & $>50$ \\
\hline Price elasticity & -2.717 & -5.642 & -5.597 & -13.750 \\
\hline Cross elasticity - group & 5.026 & 3.680 & 5.027 & 2.426 \\
\hline \multirow[t]{2}{*}{ Cross elasticity - nongroup } & 0.091 & 0.064 & 0.011 & 0.011 \\
\hline & \multicolumn{4}{|c|}{ (ii) } \\
\hline Range of speed & 0 to 5 & 6 to 20 & 21 to 49 & $>\mathbf{5 0}$ \\
\hline Price elasticity & -2.358 & -4.794 & -4.782 & -11.587 \\
\hline Cross elasticity - group & 4.145 & 3.035 & 4.141 & 1.999 \\
\hline Cross elasticity - nongroup & 0.080 & 0.056 & 0.009 & 0.010 \\
\hline
\end{tabular}

Source: Data compiled by the authors.

As shown in Table 5, whereas the price elasticity of demand for broadband services with speed up to $5 \mathrm{Mbps}$ ranges from 2.3 to 2.7, those with a speed greater than 50 Mbps have a price elasticity over 10. Speeds between 6 and 20 Mbps and between 21 and $49 \mathrm{Mbps}$ have price elasticities of demand similar to each other rather than to other speeds. The highest price elasticity of demand for broadband greater than 50 Mbps is possibly associated with the effect of satiety. Even though consumers prefer higher speeds, they are less willing to pay for speeds greater than $50 \mathrm{Mbps}$.

Note that the cross elasticity for products in the same category increases until it reaches the third range of speed. Services with speeds greater than $50 \mathrm{Mbps}$ have lower elasticities when compared to other ranges, suggesting a smaller competition between 
products in this category. Consumers of services with speeds greater than $50 \mathrm{Mbps}$ are likely less price-sensitive.

Finally, price elasticities of demand are higher when two or more economic groups offer products in the municipality. This is an intuitive finding as the monopoly will set the price for the broadband services to minimize competition between plans in the same category. Thus, the capacity of consumers to react to higher prices is undermined. This scenario changes, however, when there is more than one competitor in the market. If consumers perceive that prices are higher, they are able to replace the services with one offered by a competitor. Table 6 shows the average elasticities per number of groups in the municipality.

Table 6 - Average elasticities per number of groups in the municipality for the one-level nested logit model

\begin{tabular}{lcccc}
\hline & \multicolumn{2}{c}{ (i) } & & (ii) \\
& $\mathbf{1}$ & $\mathbf{2}$ or more & $\mathbf{1}$ & 2 or more \\
\hline Price elasticity & 4.348 & -8.241 & -4.577 & -6.950 \\
Cross elasticity - group & 5.214 & 1.958 & 3.760 & 1.616 \\
Cross elasticity - nongroup & 0.051 & 0.053 & 0.046 & 0.047 \\
\hline
\end{tabular}

Source: Data compiled by the authors.

\subsection{TWO-LEVEL NESTED LOGIT MODEL PER SPEED RANGE AND ECONOMIC GROUP}

Firm size plays an important role in the analysis of competition between broadband providers. According to ANATEL (2016), competition within the municipality will be directly affected by the presence or not of more than one large group in the fixed broadband market: 'Where there are two or more large groups, competition will be fiercer; where there is only one large group competing with smaller and non-vertically integrated firms, competition will be smaller.' In this regard, the present study uses a second model estimated by two-level nested logit in order to assess how the demand for broadband is affected in the presence of more than one large group.

In this extended model, products belonging to same-size companies and to the same range of speed are near substitutes compared to products in the same range of speed only, having a greater competition than those products in different ranges of speed. This occurs because by having same-size companies in the same group, one expects to exert more control over unobservable characteristics that could affect the supply and demand for broadband, such as brand strength, possible scale and network effects, reputation, among others. 
Therefore, consumers first decide which range of speed they are interested in and only after that they decide on the proxy for firm size (local, regional or national), as depicted in Figure 3.

Figure 3 - Decision tree for consumers of broadband services for empirical model 2

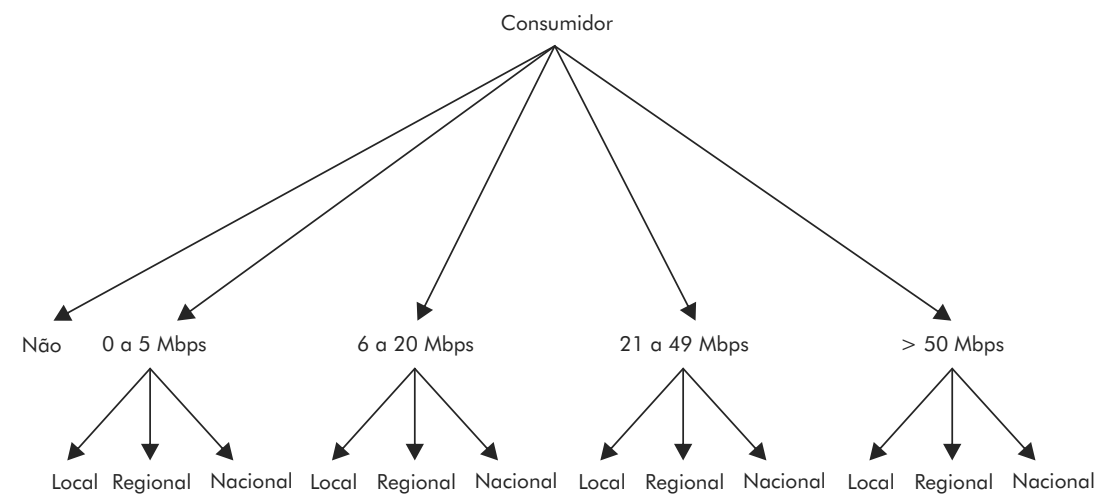

Source: Authors' elaboration based on data compiled for the analysis.

We also estimated a model with a reverse order of nests - in which consumers first choose among national, local, and regional companies and, subsequently, decide on the range of speed; and with a different categorization - regional and local firms in the same subgroup. However, these estimations yielded parameters that are inconsistent with the random utility theory $\left(\sigma_{1}<\sigma_{2}\right)$, indicating stronger correlation between the group than between the subgroup. Hence, in line with the literature (GOLDBERG, 1995, BJÖRNERSTEDT and VERBOVEN, 2013), we opted for models that were consistent with the random utility theory with correlation parameters between groups and subgroups as follows: $1 \geq \sigma_{1} \geq \sigma_{2} \geq 0$.

Oi, Telefônica, and Telecom Américas are categorized as national companies. Together, they account for $85 \%$ of broadband access in the Brazilian market, but they tend to operate in different geographical markets. Algar and Blue are regional companies. Algar operates in several towns in the south of Minas Gerais, having a large market presence in that region. Blue concentrates its operations in the south. Finally, Videomar, Televisão Cidade, Cabo, Mastercombo, and Sky ${ }^{14}$ are local companies. Table 7 shows a larger number of national rather than local companies.

14 While having a strong market presence in the pay television sector and being a strong brand, Sky was categorized as local, since it is still a small firm in the broadband market, operating in a smaller number of municipalities, when compared to national and regional companies. 
Table 7 - Number of municipalities per proxy for firm size and per number of groups that provide broadband services

\begin{tabular}{lccccc}
\hline \multicolumn{5}{c}{ Number of groups that provide broadband services in the municipality } \\
\hline Proxy for firm size & 1 & 2 & 3 & 4 & 5 \\
National & 1,580 & 160 & 141 & 89 & 27 \\
Regional & 54 & 8 & 4 & 10 & 1 \\
Local & 0 & 18 & 23 & 27 & 13 \\
\hline
\end{tabular}

Source: Authors' elaboration based on data compiled for the analysis.

Finally, as this categorization is useful only for those consumers who can choose among different companies, the model was implemented using a subsample of the previous model, including 194 municipalities with more than one economic group.

\subsubsection{RESULTS}

As discussed in Section 2, the two-level nested logit model can be estimated by GMM with the following functional form:

$$
\ln \left(s_{j}\right)-\ln \left(s_{0}\right)=\alpha p_{j}+\beta_{1}+\beta_{2} \text { Speed }_{j}+\beta_{3} \text { Wifi }_{j}+\beta_{4} \text { Bundle }_{j m}+\sigma \ln \left(\bar{s}_{j / h g}\right)+\sigma_{2} \ln \left(\bar{s}_{h / g}\right)+\theta Z+\xi_{j}
$$

Here, all variables are similar to model 1 , except for: $\bar{s}_{j / h g}=\frac{q_{j}}{\sum_{j \in H_{g}} q_{j}}$ is the market share of product $j$ in subgroup $h ; \bar{h}_{h / g}=\frac{\sum_{j \in H_{g}} q_{j}}{\sum_{h=1}^{H_{g}} \sum_{j \in H_{g}} q_{j}}$, market share of subgroup $h$ relative to group $g ; \sigma_{1}$ is the correlation of consumer's preference with products from the same subgroup $h$ of group $g ; \sigma_{2}$ is the correlation of consumer's preference with products from the subgroups of the same group $g$.

Table 8 shows the results for both specifications, which use cluster on micro region. The regional average price, average speed of the group and the number of competing offers of the subgroups are used as instruments. The first estimation also includes the number of competing offers of the group..$^{15}$ The estimations use robust standard errors for the correction of heteroskedasticity.

15 The model was also estimated with product dummies; however, the price variable was nonsignificant. 
Table 8 - Estimation results for the two-level nested logit model

\begin{tabular}{|c|c|c|}
\hline Variable & (iii) & (iv) \\
\hline \multirow[t]{2}{*}{$\ln \left(\bar{s}_{j / h g}\right)$} & .91198804 & .9194391 \\
\hline & $(0.000)$ & $(0.000)$ \\
\hline \multirow[t]{2}{*}{$\ln \left(\bar{S}_{h / g}\right)$} & .67506251 & .82861742 \\
\hline & $(0.000)$ & $(0.000)$ \\
\hline \multirow[t]{2}{*}{ Price } & -.01101813 & -.00736717 \\
\hline & $(0.000)$ & $(0.004)$ \\
\hline \multirow[t]{2}{*}{ Speed } & .01070664 & .00733026 \\
\hline & $(0.0012)$ & $(0.0204)$ \\
\hline \multirow[t]{2}{*}{ Wi-Fi dummy } & .04008373 & -.19931427 \\
\hline & $(0.8931)$ & $(0.4654)$ \\
\hline \multirow[t]{2}{*}{ Bundle dummy } & 1.0201742 & .8854934 \\
\hline & $(0.0011)$ & $(0.0063)$ \\
\hline \multirow[t]{2}{*}{ Per capta revenue } & .00099757 & .00095122 \\
\hline & $(0.000)$ & $(0.000)$ \\
\hline \multirow[t]{2}{*}{$\%$ young population } & .01826012 & .01403275 \\
\hline & $(0.4395)$ & $(0.4929)$ \\
\hline \multirow[t]{2}{*}{ MHDI Schooling } & 2.289 .971 & 2.3061636 \\
\hline & $(0.0192)$ & $(0.0156)$ \\
\hline \multirow[t]{2}{*}{$\%$ urban population } & .00853557 & .00874052 \\
\hline & $(0.0494)$ & $(0.0255)$ \\
\hline \multirow[t]{2}{*}{ Log of Area } & .00797505 & -.00224646 \\
\hline & $(0.8642)$ & $(0.9580)$ \\
\hline \multirow[t]{2}{*}{ Log of Scale } & .00174188 & .00136469 \\
\hline & $(0.000)$ & $(0.001)$ \\
\hline \multirow[t]{2}{*}{ Constant } & -5.6567152 & -4.9203451 \\
\hline & $(0.000)$ & $(0.000)$ \\
\hline Instruments & $\begin{array}{c}\text { Average regional prices; \# offers } \\
\text { by competitors; Average speed } \\
\text { on group and subgroup }\end{array}$ & $\begin{array}{c}\text { Average regional prices; \# } \\
\text { offers by competitors; Average } \\
\text { speed on subgroup }\end{array}$ \\
\hline Centered $\mathrm{R}^{2}$ & 0.8355 & 0.8385 \\
\hline Underidentification test & 26.119 & 25.014 \\
\hline Sargan & $(0.0699)$ & $(0.1975)$ \\
\hline
\end{tabular}

Note: $P$ value in brackets.

Source: Data compiled by the authors. 
The parameters of interest have the expected sign for all estimates: price has a negative sign and $\ln \left(\bar{s}_{j / h g}\right)$ and $\ln \left(\bar{s}_{h / g}\right)$ have signs and values that are consistent with the random utility theory $\left(1 \geq \sigma_{1} \geq \sigma_{2} \geq 0\right)$. Regarding the characteristics of the services, the specifications of the two-level nested logit model have the same results observed for the one-level model, except for the Wi-Fi dummy, which was no longer significant. The demographic variables of the first specification also have parameters with expected signs, yielding similar results to those of the one-level nested logit model. The dummy variable associated with the offer of triple play bundles showed positive and significant parameters for both estimates.

The specified model adapts reasonably well to the available data: regressions have a Centered $\mathrm{R}^{2}$ of 0.8355 , with average speed on group, and of 0.8385 , without average speed on group, suggesting that the models explain more than $80 \%$ of the variations in the market share of the products offered in the fixed broadband market.

After this preliminary discussion, we now discuss the price elasticities of demand and the cross elasticities estimated by the two-level nested logit model.

\subsubsection{ELASTICITIES}

As expected, the demand for broadband is elastic and its values are similar between the estimated specifications: 8.9 to $10.2 .{ }^{16}$ However, their values are relatively higher than those estimated in the one-level nested logit model.

Table 9 demonstrates that cross elasticities for products with the same range of speed and for firms of similar size hover around 2.1, which is higher than that observed for services in the same range of speed (around 0.36) and significantly higher than for products in other ranges of speed (0.02). Therefore, results indicate that firms of similar size, when they offer products in the same range of speed, exhibit greater rivalry between each other than do firms of different sizes.

Similarly to what is observed in the one-level nested logit model, products in lower ranges of speed are more inelastic when compared with other ranges. The table with these results is shown in the Appendix.

Table 10, in which elasticities are estimated according to the firm size, shows that price elasticities of demand are higher for national groups (9.3 and 10.5) than for regional groups (8.75 and 7.7) and local groups (7.0 and 6.2). However, cross elasticities for these two categories are higher than those obtained for national groups. Interestingly, the cross

\footnotetext{
16 This section presents the modules of price elasticity of demand.
} 
elasticity offered in the same range of speed, without considering firm size, is higher for regional (0.53 and 0.51$)$ and local (1.24 and 1.20) groups. This could indicate asymmetric competition, in which the market share of local and regional groups is more severely affected by the presence of groups of other sizes than is the market share of national groups. Possibly, national groups compete more with local and regional groups rather than the other way around.

Table 9 - Average elasticities for the two-level nested logit model

\begin{tabular}{lccc}
\hline & & (iii) & (iv) \\
\hline Price elasticity & Mean & -10.232 & -8.989 \\
Cross elasticity - group & S.D. & 7.707 & 6.695 \\
& Mean & 2.516 & 2.100 \\
Cross elasticity - subgroup & S.D. & 2.837 & 2.360 \\
& Mean & 0.381 & 0.365 \\
Cross elasticity - nongroup & S.D. & 0.604 & 0.581 \\
& Mean & 0.020 & 0.017 \\
\hline
\end{tabular}

Source: Data compiled by the authors.

Table 10 - Average elasticities for the two-level nested logit model, according to the proxy for firm size

\begin{tabular}{lcccccc}
\hline & \multicolumn{3}{c}{ (iii) } & \multicolumn{3}{c}{ (iv) } \\
\hline \# National groups & National & Regional & Local & National & Regional & Local \\
Price elasticity & -10.581 & -8.759 & -7.031 & -9.292 & -7.767 & -6.185 \\
Cross elasticity - subgroup & 2.274 & 3.965 & 4.509 & 1.891 & 3.301 & 3.853 \\
Cross elasticity - group & 0.298 & 0.534 & 1.247 & 0.285 & 0.514 & 1.203 \\
Cross elasticity-nongroup & 0.021 & 0.017 & 0.011 & 0.018 & 0.015 & 0.009 \\
\hline
\end{tabular}

Source: Data compiled by the authors.

Note that price elasticity of demand for broadband is positively related to the number of national economic groups, even when it is controlled for the total number of groups operating in the municipality: 2.7 and 3.0 if there is no national group, against 7.3 and 8.2 with only one national group competing with firms with different size. As shown in Table 11, the elasticity when there are two national groups competing with each other are a little bit higher than the previous case: 9.3 and 8.2. When there are tree national groups offering broadband in the municipality, the elasticity goes to 13.3 and 11.6. This indicates that competition is actually stronger in municipalities with a greater number of large economic groups. 
Table 11 - Average elasticitiesfor the two-level nested logit modelper number of national groups

\begin{tabular}{|c|c|c|c|c|}
\hline \multirow{3}{*}{$\begin{array}{l}\text { \# Total Groups } \\
\text { \# National groups }\end{array}$} & \multicolumn{4}{|c|}{ (iii) } \\
\hline & \multicolumn{2}{|c|}{2} & \multicolumn{2}{|c|}{3} \\
\hline & 0 & 1 & 2 & 3 \\
\hline Price elasticity & -3.069 & -8.248 & -9.321 & -13.304 \\
\hline Cross elasticity - subgroup & 3.065 & 5.036 & 2.543 & 2.209 \\
\hline Cross elasticity - group & 0.610 & 0.973 & 0.449 & 0.297 \\
\hline \multirow[t]{2}{*}{ Cross elasticity -nongroup } & 0.033 & 0.026 & 0.018 & 0.026 \\
\hline & \multicolumn{4}{|c|}{ (iv) } \\
\hline \# Total Groups & \multicolumn{2}{|c|}{2} & \multicolumn{2}{|c|}{3} \\
\hline \# National groups & $\mathbf{0}$ & 1 & 2 & 3 \\
\hline Price elasticity & -2.756 & -7.318 & -8.188 & -11.657 \\
\hline Cross elasticity - subgroup & 2.579 & 4.237 & 2.132 & 1.837 \\
\hline Cross elasticity - group & 0.585 & 0.937 & 0.431 & 0.284 \\
\hline Cross elasticity -nongroup & 0.028 & 0.022 & 0.015 & 0.022 \\
\hline
\end{tabular}

Source: Data compiled by the authors.

\section{CONCLUSION}

The results of this study move further away from those described in the previous literature, which seek to estimate how the demand varies as a function of the technology used for service delivery. Product characteristics, such as speed, Wi-Fi, bundled services, and characteristics of the companies, such as size, were the major determining factors for the demand for broadband.

In addition, unlike prior analyses, whose data focused mainly on state capitals, the present study included information collected from nearly 1,800 municipalities about the supply of broadband services by the major Brazilian telecommunications companies. Thus, it was possible to estimate the elasticity of demand for broadband by including information about small and medium-sized towns as well as towns outside the metropolitan area.

Following the approach proposed by Berry (1994) and Verboven (1996), we estimated the demand for differentiated products with unobservable characteristics using two discrete-choice models: one-level and two-level nested logit. The nested logit is not a general model like BLP, but can deliver good estimates of elasticity demand.

Using information on 1,830 municipalities, the first model categorized broadband services into four ranges of speed: up to $5 \mathrm{Mbps}, 5$ to $15 \mathrm{Mbps}$, 15 to $50 \mathrm{Mbps}$, and greater than $50 \mathrm{Mbs}$. This was necessary because the services with remarkably different 
speeds would not be perceived as near substitutes. Results suggest that the demand for broadband is elastic and that products in lower ranges of speed are more inelastic when compared with other ranges, which indicates that consumers are less willing to pay for speeds greater than $50 \mathrm{Mbps}$. Moreover, price elasticities of demand are higher when the service is offered by two or more economic groups, showing higher price sensitivity in municipalities where competition is stronger.

The second estimation uses a two-level nested logit model, which categorizes services per speed and includes a subgroup associated with the proxy for firm size, classifying them into national, regional, and local. In this way, services in the same range of speed, belonging to economic groups of similar size, will be closer competitors. As this categorization is useful only for those consumers who can choose among different companies, the estimations used a subsample of the one-level nested logit model, including 194 municipalities with two or more economic groups offering broadband services.

The results associated with the variation in price elasticity of demand for range of speed and with the number of competitors are consistent with those obtained in the previous model. When assessed separately by size of the economic group, price elasticities of demand are higher for national companies. However, cross elasticities at the first level show an inverse pattern, which indicates that local and regional groups compete more fiercely with companies of different size than do national groups. Therefore, there is some evidence of asymmetric competition in the market: the demand for products from smaller companies is more severely affected by the presence of national companies than the other way around.

The present study also identified a positive effect on the market share of those broadband services offered as triple play bundles. It is not possible, however, to assess whether this finding is associated with consumers' preference for bundled services or with a strategy adopted by companies to offer more attractive speeds, giving discounts if customers purchase other products.

This underscores the importance of evaluating the impact of these offers on the competition between telecommunications companies. While this commercial strategy is widely adopted in the Brazilian market, there are no other empirical analyses that estimate the impact of bundles on the demand for broadband, especially because there is a lack of robust data on the purchase of triple play bundles in the Brazilian market, mainly on the number of subscribers per company. 


\section{REFERENCES}

ANATEL - AGÊNCIA NACIONAL DE TELECOMUNICAÇÕES. Análise de impacto regulatório: reavaliação da regulamentação de mercados relevantes. 2016.

BEREC - BODY OF EUROPEAN REGULATORS FOR ELECTRONIC COMMUNICATIONS. Report on the impact of bundled offers in retail and wholesale market definition. Body of European Regulators for Electronic Communications, v. BoR (10) 64, December, 2010.

BERRY, S. T. Estimating discrete-choice models of product differentiation. RAND Journal of Economics, v. 25, n. 2, p. 242-262, 1994.

BERRY, S. T.; HAILE, P. Identification in differentiated products markets. Annual Review of Economics, v. 8, p. 27-52, 2016.

BERRY, S. T.; LEVINSOHN, J.; PAKES, A. Automobile prices in market equilibrium. Econometrica, v. 63, n. 4, p. 841-890, 1995.

BJÖRNERSTEDT, J.; VERBOVEN, F. Merger simulation with nested logit demand implementation using Stata. Konkurrensverket Working Series Paper, v. 2, 2013a.

BJÖRNERSTEDT, J.; VERBOVEN, F. Does merger simulation work? Evidence from the Swedish analgesics market. Working paper, January, 2013b.

BRESNAHAN, T. F. The apple-cinnamon cheerios war: valuing new goods, identifying market power, and economic measurement. Tim Bresnahan Webpage, Stanford University, 1997. Available at: $<$ https://web.stanford.edu/ tbres/Unpublished_Papers/hausman\%20recomment.pdf>.

BUGHIN, J. R.; MENDONÇA, P. Convergence and Triple play bundling: an empirical assessment for European telecommunications. Communications \{\&\} Strategies, v. 4, n. 68, p. 121-138, 2007.

CARDONA, M. et al. Demand estimation and market definition for broadband internet services. Journal of Regulatory Economics, v. 43, p. 1-32, July, 2007.

CORRADO, C.; UKHANEVA, O. Hedonic prices for fixed broadband services: estimation across OECD countries. OECD Science, Technology and Industry Policy Papers, v. 2016/07, 2016.

BAIGORRI, C. A estrutura concorrencial do mercado de redes de transporte de telecomunicações e os impactos de políticas de massificação da banda larga no Brasil. IX Prêmio - SEAE, 2014.

FREITAS, I. V. B.; GOMES, V. Aplicação de modelos de escolha discreta na estimação da demanda por serviços de acesso à internet. Dissertação (Mestrado em Economia) Universidade de Brasília, Brasília, 2013.

HENRIKSEN, A.; MUELLER, B. P. M. A competição no mercado de banda larga no Brasil: uma análise de possíveis determinantes da penetração do serviço de acesso à Internet em banda larga em municípios brasileiros. Dissertação (Mestrado em Economia) - Universidade de Brasília, Brasília, 2012.

IDA, T.; KURODA, T. Discrete-choice Analysis of demand for broadband in Japan. Journal of Regulatory Economics, v. 29, n. 1, p. 5-22, 2006.

KRIDEL, D. J.; RAPPOPORT, P. N., TAYLOR, L. D. "An econometric model of demand for access to the Internet by cable modem”. In LOOMIS, D. G.; TAYLOR, L. D. (Eds.). Forecasting the Internet: understanding the explosive growth of data communications. Boston: Kluwer Academic Publishers, 2001. 
MACEDO, H. R.; CARVALHO, A. X. Y. C. Aumento do acesso à internet em banda larga no Brasil e sua possível relação com o crescimento econômico: uma análise de dados em painel. Texto para Discussão, IPEA, n. 1494, mai. 2010

MACEDO, H. R.; CARVALHO, A. X. Y. C. Análise de Possíveis Determinantes da Penetração do Serviço de Acesso à Internet em Banda Larga nos Municípios Brasileiros. Texto para Discussão, IPEA, v. 1503, n. 1, p. 1-5, 2014.

MCFADDEN, D. Modeling the choice of residential location. Transportation Research Record, $\mathrm{n}$. 673 , p. $72-77,1978$.

NEVO, A. Measuring market power in the ready-to-eat cereal industry. Econometrica, v. 69, n. 2, p. 307-342, 2001.

OCDE - ORGANIZAÇÃO PARA A COOPERAÇÃO E DESENVOLVIMENTO ECONÔMICO. Triple and quadruple play bundles of communication services. OECD Science, Technology and Industry Policy Papers, n. 23, 2015.

PRINCE, J. The dynamic effects of triple play bundling in telecommunications. Time Warner Cable Research Program on Digital Communications, v. Winter 201, 2012.

VERBOVEN, F. International price discrimination in the European car market. RAND Journal of Economics, v. 27, n. 2, p. 240-268, 1996. 


\section{APPENDIX}

Table 12 - Results for estimations of the one-level nested logit model

\begin{tabular}{|c|c|c|c|c|c|}
\hline & OLS & IV-1 & IV-2 & (i) & (ii) \\
\hline \multirow{2}{*}{$\ln \left(\bar{s}_{j / g}\right)$} & .75196518 & .6968422 & .74465457 & .74233038 & .72800485 \\
\hline & $(0.000)$ & $(0.000)$ & $(0.000)$ & $(0.000)$ & $(0.000)$ \\
\hline \multirow[t]{2}{*}{ Price } & -.00640203 & -.07816025 & -.01581186 & -.01879599 & -.01666353 \\
\hline & $(0.000)$ & $(0.013)$ & $(0.000)$ & $(0.000)$ & $(0.000)$ \\
\hline \multirow[t]{2}{*}{ Speed } & -.00335801 & .06850762 & .00605993 & .00904605 & .00592498 \\
\hline & 0.0438 & $(0.028)$ & $(0.044)$ & $(0.002)$ & $(0.051)$ \\
\hline \multirow[t]{2}{*}{ Wi-Fi dummy } & -.31129912 & -15116058 & -.47087562 & -.52138864 & -.55958953 \\
\hline & 0.0083 & $(0.032)$ & $(0.001)$ & $(0.000)$ & $(0.000)$ \\
\hline \multirow[t]{2}{*}{ Bundle dummy } & .22102907 & 35068263 & 65240719 & .78921698 & 12869006 \\
\hline & 0.1287 & $(0.029)$ & $(0.002)$ & $(0.000)$ & $(0.000)$ \\
\hline \multirow[t]{2}{*}{ Per capta revenue } & .00207489 & .00118705 & .00195828 & .0019213 & .0018662 \\
\hline & 0.0000 & $(0.022)$ & $(0.000)$ & $(0.000)$ & $(0.000)$ \\
\hline \multirow[t]{2}{*}{$\%$ young population } & .01413159 & -.01326479 & .01058527 & .0094634 & .00436183 \\
\hline & 0.1686 & $(0.425)$ & $(0.304)$ & $(0.353)$ & $(0.659)$ \\
\hline \multirow[t]{2}{*}{ MHDI - Schooling } & 4501507 & 40453439 & 44431489 & 44.247 .239 & 43486739 \\
\hline & $(0.000)$ & $(0.000)$ & $(0.000)$ & $(0.000)$ & $(0.000)$ \\
\hline \multirow[t]{2}{*}{$\%$ urban population } & .02013414 & .01298463 & .01919972 & .0189036 & .01855084 \\
\hline & $(0.000)$ & $(0.000)$ & $(0.000)$ & $(0.000)$ & $(0.000)$ \\
\hline \multirow[t]{2}{*}{ Log of Scale } & .00112104 & .00149023 & .00116889 & .00118402 & .00111909 \\
\hline & $(0.000)$ & $(0.000)$ & $(0.000)$ & $(0.000)$ & $(0.000)$ \\
\hline \multirow[t]{2}{*}{ Telefônica } & - & - & - & - & .90820531 \\
\hline & & & & & $(0.000)$ \\
\hline \multirow[t]{2}{*}{ Constant } & -10678405 & .22001024 & -92501164 & -8.797 .403 & -93414778 \\
\hline & $(0.000)$ & $(0.964)$ & $(0.000)$ & $(0.000)$ & $(0.000)$ \\
\hline Instruments & - & $\begin{array}{l}\text { \# of offers by } \\
\text { competitors }\end{array}$ & $\begin{array}{c}\text { Average } \\
\text { regional prices }\end{array}$ & \multicolumn{2}{|c|}{$\begin{array}{c}\text { \# of offers by competitors and } \\
\text { Average regional prices }\end{array}$} \\
\hline $\mathrm{R}^{2}$ & 0.7056 & 0.2109 & 0.6970 & 0.6908 & 0.7007 \\
\hline F Test & - & 12.78 & 37.90 & - & - \\
\hline Sargan (p-value) & - & - & - & 0.0109 & 0.0315 \\
\hline
\end{tabular}

Source:Data compiled by the authors based on data provided by ANATEL and IBGE and information collected for the analysis. 
Table 13 - Average elasticities for the one-level nested logit model

\begin{tabular}{lcccccc}
\hline & & OLS & IV-1 & IV-2 & (i) & (ii) \\
\hline Price elasticity & Mean & -1.883 & -19.901 & -4.552 & -5.376 & -4.582 \\
& S.D. & 1.510 & 14.551 & 3.606 & 4.241 & 3.529 \\
Cross elasticity - group & Mean & 1.560 & 14.491 & 3.708 & 4.355 & 3.590 \\
& S.D. & 1.059 & 9.819 & 2.516 & 2.954 & 2.435 \\
$\begin{array}{l}\text { Cross elasticity - } \\
\text { nongroup }\end{array}$ & Mean & 0.017 & 0.213 & 0.043 & 0.051 & 0.045 \\
& S.D. & 0.026 & 0.321 & 0.065 & 0.077 & 0.068 \\
\hline
\end{tabular}

Source: Data compiled by the authors

Table 14 - Estimation results for the two-level nested logit model

\begin{tabular}{|c|c|c|c|c|c|c|}
\hline Variable & OLS & IV-1 & IV-2 & IV-3 & (iii) & (iv) \\
\hline \multirow{2}{*}{$\ln \left(\bar{s}_{j / h g}\right)$} & .92317075 & .92096751 & .88786967 & .91678846 & .91198804 & .9194391 \\
\hline & $(0.000)$ & $(0.000)$ & $(0.000)$ & $(0.000)$ & $(0.000)$ & $(0.000)$ \\
\hline \multirow{2}{*}{$\ln \left({\overline{S_{h / g}}}\right)$} & .89256121 & .85402398 & .30850405 & .78696603 & .67506251 & .82861742 \\
\hline & $(0.000)$ & $(0.000)$ & $(0.4644)$ & $(0.000)$ & $(0.000)$ & $(0.000)$ \\
\hline \multirow[t]{2}{*}{ Price } & -.00283702 & -.00558684 & -.04372195 & -.01022885 & -.01101813 & -.00736717 \\
\hline & $(0.000)$ & $(0.0137)$ & $(0.1496)$ & $(0.000)$ & $(0.000)$ & $(0.004)$ \\
\hline \multirow[t]{2}{*}{ Speed } & .00240728 & .00539462 & .0468635 & .01044478 & .01070664 & .00733026 \\
\hline & $(0.0847)$ & $(0.0936)$ & $(0.1667)$ & $(0.0017)$ & $(0.0012)$ & $(0.0204)$ \\
\hline \multirow[t]{2}{*}{ Wi-Fi dummy } & -.30092761 & -.24049991 & .64692203 & -.12956021 & .04008373 & -.19931427 \\
\hline & $(0.2229)$ & $(0.3746)$ & $(0.4257)$ & $(0.6298)$ & $(0.8931)$ & $(0.4654)$ \\
\hline \multirow[t]{2}{*}{ Bundle dummy } & .69624546 & .81144579 & 23.956 .895 & 10.034 .981 & 10.201 .742 & .8854934 \\
\hline & $(0.0069)$ & $(0.0100)$ & $(0.0967)$ & $(0.0018)$ & $(0.0011)$ & $(0.0063)$ \\
\hline \multirow[t]{2}{*}{ Per capta revenue } & .0009407 & .00094638 & .00105436 & .00096125 & .00099757 & .00095122 \\
\hline & $(0.001)$ & $(0.000)$ & $(0.0023)$ & $(0.001)$ & $(0.000)$ & $(0.000)$ \\
\hline \multirow[t]{2}{*}{$\%$ young population } & .01230007 & .01349905 & .0240298 & .01442076 & .01826012 & .01403275 \\
\hline & $(0.5539)$ & $(0.5103)$ & $(0.3834)$ & $(0.4803)$ & $(0.4395)$ & $(0.4929)$ \\
\hline \multirow[t]{2}{*}{ MHDI - Schooling } & 23.782 .773 & 23.370 .078 & 16.591 .769 & 22.482 .668 & 2.289 .971 & 23.061 .636 \\
\hline & $(0.0198)$ & $(0.0152)$ & $(0.4470)$ & $(0.0191)$ & $(0.0192)$ & $(0.0156)$ \\
\hline \multirow[t]{2}{*}{$\%$ urban population } & .00913629 & .0089265 & .00474085 & .00834161 & .00853557 & .00874052 \\
\hline & $(0.0209)$ & $(0.0220)$ & $(0.5288)$ & $(0.0349)$ & $(0.0494)$ & $(0.0255)$ \\
\hline \multirow[t]{2}{*}{ Log of Area } & -.00456989 & -.00325578 & .0189915 & -.00031009 & .00797505 & -.00224646 \\
\hline & $(0.9122)$ & $(0.9385)$ & $(0.7849)$ & $(0.9943)$ & $(0.8642)$ & $(0.9580)$ \\
\hline Log of Scale & .00142951 & .00138788 & .00090588 & .00133484 & .00174188 & .00136469 \\
\hline
\end{tabular}


Table 14 - Estimation results for the two-level nested logit model

\begin{tabular}{|c|c|c|c|c|c|c|}
\hline Variable & OLS & IV-1 & IV-2 & IV-3 & (iii) & (iv) \\
\hline \multirow{3}{*}{ Constant } & $(0.0003)$ & $(0.001)$ & $(0.0957)$ & $(0.002)$ & $(0.000)$ & $(0.001)$ \\
\hline & -49.868 .696 & -49.537 .414 & -41.879 .264 & -48.424 .239 & -56.567 .152 & -49.203 .451 \\
\hline & $(0.001)$ & $(0.000)$ & $(0.1546)$ & $(0.001)$ & $(0.000)$ & $(0.000)$ \\
\hline Instruments & - & $\begin{array}{c}\text { Average } \\
\text { regional } \\
\text { prices }\end{array}$ & $\begin{array}{l}\text { \# offers by } \\
\text { competitors }\end{array}$ & $\begin{array}{l}\text { Average } \\
\text { speed on } \\
\text { group and } \\
\text { subgroup }\end{array}$ & All & $\begin{array}{l}\text { All but } \\
\text { average } \\
\text { speed on } \\
\text { group }\end{array}$ \\
\hline $\begin{array}{l}\text { Underidentification } \\
\text { test }\end{array}$ & - & 19.652 & 3.451 & 19.320 & 26.119 & 24.875 \\
\hline Sargan & - & $(0.000)$ & $(0.000)$ & $(0.0102)$ & $(0.0699)$ & $(0.1975)$ \\
\hline
\end{tabular}

Note: P value in brackets.

Source: Data compiled by the authors.

Table 15 - Average elasticities for the two-level nested logit model

\begin{tabular}{lccccccc}
\hline & & OLS & IV-1 & IV-2 & IV-3 & (iii) & (iv) \\
\hline Priceelasticity & Mean & -3.864 & -7.079 & -35.298 & -11.832 & -10.232 & -8.989 \\
& S.D. & 2.705 & 5.168 & 29.136 & 9.029 & 7.707 & 6.695 \\
Cross elasticity - group & Mean & 0.614 & 1.493 & 11.986 & 3.074 & 2.516 & 2.100 \\
& S.D. & 0.699 & 1.671 & 13.993 & 3.482 & 2.837 & 2.360 \\
Cross elasticity - subgroup & Mean & 0.237 & 0.333 & 0.292 & 0.393 & 0.381 & 0.365 \\
& S.D. & 0.380 & 0.531 & 0.427 & 0.622 & 0.604 & 0.581 \\
Cross elasticity - nongroup & Mean & 0.007 & 0.013 & 0.101 & 0.024 & 0.020 & 0.017 \\
& S.D. & 0.010 & 0.012 & 0.160 & 0.037 & 0.031 & 0.027 \\
\hline
\end{tabular}

Source: Data compiled by the authors.

Table 16 - Average elasticities per range of speed, in Mbps, for the two-levelnested logit model

\begin{tabular}{lcccccccc}
\hline & \multicolumn{3}{c}{ (iii) } & \multicolumn{5}{c}{ (iv) } \\
Range of speed & 0 to 5 & 6 to 20 & 21 to 49 & $>50$ & 0 to 5 & 6 to 20 & 21 to 49 & $>50$ \\
\hline $\begin{array}{l}\text { Price elasticity } \\
\begin{array}{l}\text { Cross elasticity - } \\
\text { subgroup }\end{array}\end{array}$ & -4.739 & -8.004 & -10.143 & -16.265 & -4.163 & -6.993 & -8.890 & -14.196 \\
$\begin{array}{l}\text { Cross elasticity - } \\
\text { group }\end{array}$ & 0.667 & 2.803 & 2.266 & 2.102 & 2.277 & 2.360 & 1.849 & 1.700 \\
$\begin{array}{l}\text { Cross elasticity - } \\
\text { nongroup }\end{array}$ & 0.690 & 0.175 & 0.061 & 0.641 & 0.660 & 0.168 & 0.058 \\
\hline
\end{tabular}

Source: Data compiled by the authors. 